\title{
EXECUTIVE COMPENSATION IN CLOSE CORPORATIONS: THE NEED FOR A MODIFIED JUDICIAL APPROACH TO THE REASONABLENESS TEST
}

The problem of compensating corporate executives reflects a basic conflict of interest inherent in the nature of the modern corporation-the conflict between "absentee shareholders" and salaried management. ${ }^{1}$ Both in England and in America, the corporation has historically been viewed as a vehicle whereby "skilled entrepreneurs" employ large accumulations of capital for the benefit of "absentee owners." In the traditional view, both entrepreneurs and shareholders derived income from the enterprise only as a function of its prosperity. In the modern corporate setting, however, salaried executives frequently receive generous compensation without regard to commensurate corporate prosperity, often to the detriment of the interests of the "absentee owners." While this tendency is more readily discernible in the publicly held corporation, where the divorce of control from ownership is almost axiomatic, ${ }^{3}$ similar patterns may

1. See Mautz \& Rock, The Wages of Management, 11 U. FLA. L. REv. 474, 475 (1958). The possibility of a diversity of interest among the participants in a corporation is noted in $C$. Israels, Corporate Practice $§ 1.02$, at 26 (2d ed. 1969). See also A. Berle \& G. Means, The Modern Corporation and Private Property I12-14 (rev. ed. 1967); C. Rohrlich, LAW AND Practice IN CORPorate CONTROL I-2 (1933).

THE FOLLOWING HEREINAFTER CITATIONS ARE USED IN THIS NOTE:

W. Fletcher, Cyclopedia of the Law of Private Corporations (rev. ed. 1963) [hereinafter cited as FLETCHER];

F. O'Neal, Close Corporations (197I) [hereinafter cited as O'Neai];

G. Washington \& V. RothschiLd, Compensating the Corporate Executive (3d ed. 1962) [hereinafter cited as WASHINGTON \& ROTHSCHILD].

2. See generally Gower, Some Contrasts Between British and American Corporation Law, 69 HaRv. L. REv. 1369, 1375 (1956). This view, of course, is applicable primarily to the publicly owned corporation; the small enterprise which becomes incorporated may have no "absentee owners," since all stockholders are frequently managers who control the operation of the enterprise.

For a treatment of the historical development of corporations in England and the United States, see generally BerLe \& MEANS, supra note I, at 1I-17; I J. Davis, Corporations: A Study of the Origin and Development of Great Business Combinations and of Their Relation to the Authority of the State (1905); I Fletcher $\$$ 1-2. See also 1 F. PolLOCK \& F. MAITLAND, A History OF ENGLiSh COMMON LAW 486-511 (2d ed. 1898); Williston, History of the Law of Business Corporations Before 1800, 2 HARv. L. REv. 105 (1888).

3. See generally BerLe \& MEANS, supra note 1, at xii-xxv, 112-16. 
also exist in the closely-held corporation, where the initial identity of ownership and management frequently disintegrates. ${ }^{4}$

Before the advent of large, publicly held companies, dominant directors were often able to manage corporate affairs without substantial reliance upon the expertise of highly-compensated officers. ${ }^{\circ}$ In this setting, executive compensation posed few problems, since the dominant executives were also the directors. Corporate directors were presumed to serve gratuitously, at least in their capacities as directors, and looked to the increased value of their stockholdings rather than to compensation for their financial rewards. ${ }^{\circ}$ With the evolution of the public-issue corporation and the rise of the highlysalaried "outsider" executive, however, conflicts unavoidably arose between absentee shareholders and salaried management over the extent to which compensation of corporate executives intruded upon an equitable return on the shareholder's investment. As a result, widespread litigation ensued over the legality of allegedly excessive compensation of corporate managers. ${ }^{7}$ In the majority of suits involving compensation patterns in both closely-held and public-issue corporations, the courts have tended to employ the same judicial doc-

4. See generally 2 O'NeAL $\$ 8.12$, at 99; Bradley, Toward a More Perfect Close Corporation-The Need for More and Improved Legislation, 54 GEo. L.J. 1145, 1157 (1966); Symposium, 52 Nw. U.L. Rev. 345, 375-84 (1957). See also Note, Mandatory Arbitration as a Remedy for Intra-Close Corporate Disputes, 56 VA. L. Rev. 271 (1970), noting that "breakdown occurs more frequently in close corporations than in other modes of business organization because the participants usually have no easy way out." Id. at 271 . Even if the minority shareholder continues to serve as an officer, thereby retaining the identity of ownership and management at least in theory, he may be able to exercise little or no control. See RoHRLich, supra note 1 , at 210-11.

5. See Mautz \& Rock, supra note 1, at 476. See also Berle \& MeAns, supra note 1, at 4.

6. See National Loan \& Inv. Co. v. Rockland Co., 94 F. 335, 337 (8th Cir. 1899); Navco Hardwood Co. v. Bass, 214 Ala. 553, 108 So. 452 (1925). See also H. Ballantine, CoRporations $\S 73$ (rev. ed. 1946); 2 O'NeAL $\S 8.10$, at 82. The principle underlying the rule disallowing compensation to directors acting qua directors, in the absence of express provision to the contrary, was that "the directors are trustees for the stockholders and the corporation, and the law does not imply any promise to pay trustees for performing their duties as such . . . ." 5 FLetCHER $\$ 2110$, at 505 (emphasis added). See also Nashville Breeko Block \& Tile Co. v. Hopton, 29 Tenn. App. 394, 407, 196 S.W.2d 1010, 1016 (1946).

7. The events of 1929 and the ensuing Depression served as a catalyst for this onslaught of shareholder litigation. See 2 WASHINGTON \& RothSCHILD 848. One critical case in this regard was Rogers v. Hill, 289 U.S. 582 (1933), in which a shareholder-plaintiff attacked a by-law and amounts paid to the president and vice-president thereunder. See notes 49-52 infra and accompanying text.

8. The tendency to utilize the same standard in both public-issue and close corporation cases has continued despite the growing recognition of the structural and operational differences between the two types of corporations. See generally I O'NEAL $\S 1.01$, at 2; Bradley, supra 
trine. ${ }^{8}$ Invocation by courts of the "business judgment" rule, ${ }^{9}$ a principle which entails judicial deference to directorial discretion with respect to internal corporate affairs, has served to frustrate the efforts of minority shareholders to limit excessive executive compensation.

This Note will examine the general judicial response to efforts by minority shareholders to limit allegedly excessive executive compensation, while attempting to isolate the unique problems potentially facing the unsalaried, minority shareholder in the close corporation. Examination of the case law dealing with the problem of excessive compensation indicates that an exaggerated judicial deference to the business judgment of directors has precluded effective application of an evolving reasonableness test to challenge compensation schemes. ${ }^{10}$ Moreover, it seems apparent that the reasonableness test as actually applied by the courts in compensation litigation manifests an undue preoccupation with the executive's right to reasonable compensation. The result of this emphasis is, in effect, to preclude due consideration of the minority shareholder's right to a fair dividend return. In view of certain situations unique to the close corporation, modified judicial criteria are clearly needed in scrutinizing the reasonableness of executive compensation.

\section{Non-Judicial Restraints on Executive Compensation: Inapplicability to Close Corporations}

While an analysis of the patterns of excessive compensation in publicly held corporations is not within the scope of this discussion, it should be observed that certain restraints, which are largely inapplicable to the close corporation, operate as a moderating influence

note 4; Folk, Corporation Statutes: 1959-1966, 1966 DUKE L.J. 875, 946; O'Neal, Developments in the Regulation of the Close Corporation, 50 CORNELL L.Q. 64I (1965).

9. See generally BALLANTINE, supra note 6 , at $\S 63 a ; 3$ FLETCHER $\S 1039$, at $621-28$. The business judgment rule has heen outlined as follows: "The basis of the rule is the wide latitude that directors of a corporation are given in the management of the affairs of a corporation provided always that [their] judgment, and that means an honest, unbiased judgment, is reasonably exercised by them." 3 FLETCHER $\S 1039$, at 625 . The rule has also been described as a principle "of law which protects directors from liability for business decisions that are made observing the standards of due care." Evans v. Armour \& Co., 241 F. Supp. 705, 713 (E.D. Pa. 1965). See also Kelly v. Bell, 254 A.2d 62, 75 (Del. Ch. 1969), citing Warshaw v. Calhoun, 221 A.2d 487, 492-93 (Del. Ch. 1966), wherein it was held that "[i]n the absence of a showing of bad faith on the part of the directors or a gross abuse of discretion the business judgment of the directors will not be interfered with by the courts."

10. See note 45 infra and accompanying text. See generally 2 WASHINGTON \& ROTHSCHILD 852. 
on executive compensation in publicly held companies. Primarily, public-issue corporations are subject to federal securities regulation, including proxy rules requiring disclosure of certain compensation schemes, such as stock option and group benefit plans. ${ }^{11}$ Where "insider" trading pursuant to stock option plans produces short-swing profits, executives and directors may be held liable to the corporation for such illegal profits under the Securities Exchange Act of $1934 .{ }^{12}$ Moreover, where executive compensation is inordinately high, disclosure of the compensation scheme can possibly result in adverse publicity for the corporation. ${ }^{13}$ Similarly, unfavorable publicity may attend the mere instigation of derivative actions attacking compensation plans in the case of the larger publicly held corporations, whose interests in preserving a respectable public image can be expected to provide at least a modicum of restraint upon the level of executive compensation. ${ }^{14}$ In addition, the shareholder in a widely-held corporation who objects to compensation policy normally has the alternative of selling his shares on the open market at the prevailing price. ${ }^{15}$ This "remedy" is largely unavailable to the close corporation shareholder, whose shares are normally subject to strict restrictions on transferability.$^{16}$ Moreover, even if the stock is legally transferable,

11. 17 C.F.R. 240.14a-101, Items $7 \& 9$ (1972). See generally 2 WASHINGTON \& ROTHSCHILD 832-37. It should also be noted that the issuance of stock pursuant to a stock option or profit-sharing plan may require registration under section 5(a) of the Securities Act of 1933,15 U.S.C. $\S 77($ e) (1972), inasmuch as the plan may contemplate a "public offering" within the ambit of the 1933 Act, even though only the issuer's employees are the offerees. See SEC v. Ralston Purina Co., 346 U.S. 119 (1953).

12. Securities Exchange Act of 1934, § 16(b), 15 U.S.C. $\S 78 p(b)$ (1970). See generally 2 L. Loss, Securtties Regulation 1037-1132 (1961); 2 Washington \& RothsChILd 837-47. A recent Supreme Court decision has granted judicial approval to the split-sale device, whereby liability under $\S 16(\mathrm{~b})$ can be partially avoided by disposing of one's holdings in two separate transactions. Reliance Elec. Co. v. Emerson Elec. Co., 404 U.S. 418 (1972). See generally Note, Reliance Electric and 16(b) Litigation: A Return to the Objective Approach?, $58 \mathrm{VA}_{\mathrm{A}}$ L. Rev. 907 (1972). As a result, insider trading by executives or directors pursuant to stock option plans may no longer result in such extensive liability if the split-sale device is employed.

13. Litigation or the possibility of litigation and, to a greater extent, sensitivity to publicity resulting from disclosure requirements have probably brought down compensation levels, or at least kept compensation levels lower than they might otherwise have been. 2 Washington \& RothSCHILD 921.

14. See id. 921; Comment, The Worth of a Man: A Study of Reasonable Compensation in Close Corporations, 38 S. Cal. L. Rev. 269-70 (1965).

15. See Comment, Proposals to Help the Minority Stockholder Receive Fair Divldend Treatment from the Closely Held Corporation, 56 Nw. U.L. REv. 503, 507-08 (1961). See also Note, Arbitration as a Means of Setting Disputes Within Close Corporations, 63 ColUM. L. REv. 267 (1963). 
the shares may well have limited marketability. Finally, and again resulting from the high liquidity of its stock, the publicly held corporation is under far greater pressure to declare dividends at a consistent rate than is the close corporation. ${ }^{17}$

Whatever their efficacy with respect to publicly held companies, these non-judicial restraints on levels of compensation have little or no applicability to close corporations. Since stock in close enterprises is not offered for public sale, federal securities regulations are largely inapplicable to compensation schemes involving the issue and sale of stock in closely-held corporations. Moreover, state statutory regulation of executive compensation may be properly characterized as more permissive than restrictive. For example, current statutes tend to condone, or to authorize explicitly, the establishment of the level of compensation for executive officers by a board of directors which includes the officers whose salaries are to be fixed. ${ }^{18}$

16. See generally IsRaELS, supra note I, at $\$ 4.03(2), 4.05 ; 2$ O'NEAL $\$ 7.01-.29$. The practical effect of restricting transferability is to grant "a veto on the admission of a new partner." ISRAELS, supra, $\$ 4.03(2)$, at $8 \mathrm{I}$. It should be noted, however, that restrictions on alienation are subject to the limitation of reasonableness. An absolute restraint on alienation is invalid. 2 O'NEAL $\S 7.06$, at I8; Hornstein, Stockholders' Agreements in the Closely Held Corporation, 59 Y ALE L.J. 1040, 1048 (1950). As to the meaning of "reasonableness" in the context of restrictions on transferability, see Tu-Vu Drive-In Corp. v. Ashkins, 61 Cal. 2d 283, 391 P.2d 828, 38 Cal. Rptr. 348 (1964).

A common form of restriction grants the corporation, the officers, directors, or shareholders a first option to purchase shares which a stockholder seeks to sell. For a recent case sustaining a first option provision, see Ling \& Co. v. Trinity Sav. \& Loan Ass'n, 482 S.W.2d 841 (Tex. 1972).

17. The declaration of dividends is an important factor in maintaining the stock's attractiveness to investors:

[D]irectors of a large, public-issue corporation will normally find it desirable to declare a regular dividend when profits are sufficient in order to keep their shareholders satisfied and to assure a favorable market for their shares. Directors of a small, closely held corporation, however, are often not interested in making their shares attractive to corporate investors since they may prefer to raise capital through debt transactions in order to perpetuate those presently in control . . . . [I]f the shareholder in a public issue concern is dissatisfied, he can usually sell his shares for the prevailing market price and exit as an owner of the corporation. Comment, Proposals to Help the Minority Stockholder Receive Fair Dividend Treatment from the Closely Held Corporation, supra note 15, at 507-08.

18. See, e.g., WIS. STAT. ANN. \$180.31 (1957), which provides in pertinent part:

Unless otherwise provided in the articles of incorporation or bylaws, the board of directors, by the affirmative vote of a majority of the directors then in office, and irrespective of any personal interest of any of its members, shall have the authority to establish reasonable compensation of all directors for services to the corporation as directors, officers or otherwise, or to delegate such authority to an appropriate committee (emphasis added). 
In many close corporations, however, the salaried offieers and directors often constitute the total shareholder group, and excessive compensation works to no one's disadvantage. ${ }^{19}$ However, this identity of shareholders and management frequently breaks down. A dominant faction on the board of directors may "squeeze out" a disfavored direetor-officer from his salaried position, ${ }^{20}$ with the result that the director must rely upon dividend returns for his income from the enterprise. In addition, upon the death of a director-officer, his shares may pass to his heirs, who typically do not participate in the active management of the enterprise. ${ }^{21} \mathrm{~A}$ divergence of interests between salaried officers-the active shareholders-and unsalaried, passive shareholders is likely to lead to sharp conflict over compensation and dividend policy. In such a conflict, the unsalaried, minority shareholder is obviously at a distinct disadvantage. Not only is he largely powerless to alter the corporation's policy, but the limited transferability of his shares may sharply curtail his ability to dispose of his

See also Cal. Corp. Code ANn. $\S 820$ (West 1955); Del. Code ANN. tit. 8, $\S 144$ (a) (Supp. 1968); Ill. Rev. Stat. ANN. ch. 32, § 157.33 (Smith-Hurd 1967); Mich. Stat. ANN. \& 21.13 (1963); N.Y. Bus. CoRP. LAW $\S 713$ (McKinney 1963), as amended, (Supp. 1970); N.C. GEN. Stat. § 55-30 (1965); OHto Rev. CODE ANN. tit. 17, § 1701.60 (Anderson 1964); UTAH CodE ANN. \$ 16-10-33 (1953).

19. 2 WASHINGTON \& ROTHSCHILD 849,851 . See 1SRAELS, supra note 1 , $\$ 4.02$, at 79.80; Note, Statutory Assistance for Closely Held Corporations, 71 HaRv. L. REV. 1498 (1958). Actually, the roles of shareholder, director, and officer are all normally filled by the same persons in the close corporation. 2 WASHINGTON \& ROTHSCHILD 849.

20. See 2 O'Neal $\S 8.12$, at 99. See generally F. O’Neal \& J. Derwin, Expulsion or OPPRESSion of Business Associates: "SqueEze-Outs" in SMall EnTERPRises $§ 3.05$ (1961). The classic case involving a squeeze-out of an officer-director is Carr v. Kimball, 153 App. Div. 825, 139 N.Y.S. 253 (Sup. Ct. 1912). In Carr, the president of the corporation attempted to increase his salary and reduce the compensation of the secretary-treasurer, who objected strenuously to both actions. The resulting dispute led to a scheme among the majority stockholders, including the president, pursuant to which the secretary-treasurer was removed from the board of directors. At a meeting of the reconstituted hoard, the secretary-treasurer, who was a stockholder as well, was replaced. Until the institution of the action by the dismissed officer, he was not employed by the corporation in any capacity. Indeed, the "directors excluded [the plaintiff] from the employment of [the] company, from access to its place of business, books, and records. . . ." Id. at 831, 139 N.Y.S. at 257. See also Lockley v. Robie, 276 App. Div. 291, 94 N.Y.S.2d 335 (Sup. Ct.), modified and affd, 301 N.Y. 371, 93 N.E.2d 895 (1950).

21. See O'Neal \& Derwin, supra note 20, $\$ 2.03-.04$, at 13-15. See also In re Radom \& Neidorff, Inc., 307 N.Y. 1, 119 N.E.2d 563 (1954) (where subsequent to a co-founder's death, conflicts arose between the surviving founder, who managed the business by himself, and the widow of the co-founder, who inherited her husband's stock interests); Connelly v. Weisfeld, 142 N.J. Eq. 406, 59 A.2d 869 (1948).

A method for avoiding this type of intra-corporate dispute is.the granting of an option to purchase a decedent-stockholder's shares in the corporation. See IsRaELS, supra note 1, at $\$ 4.09$. 
shares at a favorable price should he desire to do so..$^{22}$

Compensation of Officers or Dividends for Shareholders: The Dilemma of Profit Distribution in Close Corporations

As a rule, most shares in a close corporation are owned by salaried officers. ${ }^{23}$ These officer-shareholders invariably derive the bulk of their income from the corporation in the form of compensation, rather than from dividend returns. ${ }^{24}$ The reliance on dividends for realization of income, which is characteristic of shareholders in publicly held corporations, applies in the close corporation setting only to the unsalaried shareholder, ${ }^{25}$ who may represent only a minority interest.

The tendency by officers in the close corporation to rely upon salary income, as opposed to dividend returns, is largely dictated by tax considerations. ${ }^{28}$ Declaration of dividends results in double taxation: profits from which dividends are declared are taxable as corporate income, ${ }^{27}$ and the cash dividends themselves are taxable to the shareholders as personal income. ${ }^{28}$ In contrast, distributing profits in the form of executive compensation results in a tax deduction to the corporation to the extent that such compensation is deemed "reasonable" by the Commissioner ${ }^{29}$ Therefore, salaried shareholders in the close corporation can increase their return on total

22. See Comment, supra note 15, at 507-08. See generally 2 O'NEAL $\$ 7.01-.29$. Restrictions on transferability of stock tend to ensure that the corporation will remain "close" and prevent the purchase of shares by parties which are unfriendly to the corporation. Id. $\S 7.02$, at 4 . It should be observed in this regard, however, that an absolute restriction on the alienability of shares will not likely be upheld. Id. $\$ 7.06$, at 18 . See note 16 supra.

23. See 1 O'Neal $\$ 1.07$, at 21 .

24. Id. at 21-22.

25. 2 O'NeAL $\$ 8.08$, at 58 .

26. See generally Alvarez, The Deductibility of Reasonable Compensation in the Close Corporation, II SANTA ClaRa LAwYer 20 (1970); Murdock, A Primer for Compensating Executives in Closely-Held Corporations, 50 CHI. B. REC. 146 (1968); Klaus, $A$ Corporate Quandary: Search for an Adequate Method of Executive Compensation, 4 Tulsa L.J. 197 (1967).

27. INT. REv. CODE OF I954, \$ $\$ 1,61,63$.

28. Id. $\S 61(\mathrm{a})$.

29. Id. $\$$ 162(a)(1). The section provides that a deduction shall be allowed for "a reasonable allowance for salaries or other compensation for personal services actually rendered. . . ." The test of deductibility is whether the compensation payments "are reasonable and are in fact payments purely for services." Treas. Reg. $\$ 1.162-7$ (a) (1972). It is further provided that "[a]ny amount paid in the form of compensation, but not in fact as the purchase price of services, is not deductible. An ostensible salary paid by a corporation may be a distribution of a dividend on stock." Id. $\S 1.162-7(\mathrm{~b})(1)$. 
investment by maximizing salary compensation at the expense of dividend returns. ${ }^{30}$ This compensation policy, however, may be inconsistent with the interests of the unsalaried shareholder, who relies upon dividends for his income from the corporation.

In addition to the economic factors militating against dividend declaration in the close corporation, a formidable gauntlet of obstacles stands between the unsalaried, minority shareholder and equitable dividend treatment. Quite obviously, he is likely to receive little sympathy from the board of directors, which is usually controlled by the salaried officers whose economic interests lie in maximum compensation and minimum dividends. As a minority shareholder, he is typically powerless to oust individual directors, who invariably control enough shares to assure their incumbency. ${ }^{31}$ Moreover, restrictions on the transferability of close corporation stock may force the objecting shareholder to sell at a low price, which is frequently determined by book value, to existing shareholders if he desires to withdraw his investment. ${ }^{32}$ In such circumstances, recourse to litigation may be the only viable alternative for the dissident shareholder.

A variety of judicial remedies is available to the minority shareholder who seeks to restrain excessive executive compensation. Depending upon the circumstances, he may seek one or more of the following forms of relief: an accounting; ${ }^{33}$ restoration of funds to

30. See 2 WASHINGTON \& RothSCHILD 851 . It is interesting to note that the smaller the corporation, the larger is the relative magnitude of deductions taken for compcnsation. See Taxation of Corporate Enterprise 35 (TNEC Monograph No. 9, 1941), cited in 2 WASHINGTON \& RoTHSCHILD 850. This phenomenon suggests that executives in larger corporations, who are presumably in higher tax brackets, might choose to receive personal tax advantages by deferring compensation which exceeds certain levels.

31. See O'NEAL \& DERWIN, supra note 20, $§ 1.03,5.08$. Majority shareholder domination of the election of directors can be partially thwarted where cumulative voting is in effect. However, in many states cumulative voting is permissive rather than mandatory, which mcans that cumulative voting will not be required unless provided for in the corporate chartcr. But even where cumulative voting is mandatory, it may be circumvented by various devices, such as reducing the size of the board. $I d$. $\$ 5.08$.

32. See 2 O'NEAL $\$ 7.24 a$, at 86 . The unsatisfactory nature of this mcthod of price determination from the vendor's standpoint is that "[t]he book value of corporate assets [constitutes] an unreliable guide to tbe true worth of a going business, and consequently the book value of corporate shares is an unreliable standard by which to determine their worth." Id. For a listing of other methods by which the sales price of restricted shares is determined, see id. $\$ 7.24$, at 84.

33. See, e.g., Hurt v. Cotton States Fertilizer Co., 159 F.2d 52 (5th Cir.), cert. denied, 331 U.S. 828 (1947); Meiselman v. Eberstadt, 39 Del. Ch. 563, 170 A.2d 720 (Ch. 1961); Binz v. St. Louis Hide \& Tallow Co., 378 S.W.2d 278 (Mo. Ct. App. 1964); First Westchester Nat'1 Bank v. Olsen, 19 N.Y.2d 342, 227 N.E.2d 24, 280 N.Y.S.2d 117 (Ct. App. 1967); Sandfield v. Goldstein, 33 App. Div. 2d 376, 308 N.Y.S.2d 25 (Sup. Ct. 1970); Baker v. Cohn, 291 N.Y. 
the corporation; ${ }^{34}$ an injunction to prevent payment of excessive salaries; ${ }^{35}$ damages; ${ }^{36}$ limitations on in futuro compensation; ${ }^{37}$ or the declaration of a dividend..$^{38}$ The shareholder may sue derivatively, ${ }^{39}$ individually, ${ }^{40}$ or as the representative of a class. ${ }^{41}$ Yet, regardless of the remedy which the minority shareholder seeks, he faces formidable obstacles in obtaining judicial relief, inasmuch as courts have been consistently reluctant to interfere with directorial discretion as to what constitutes reasonable executive compensation. ${ }^{42}$

762, 52 N.E.2d 965, 42 N.Y.S.2d 159 (Sup. Ct.), modified, 266 App. Div. 715, 40 N.Y.S.2d 623 (Ist Dep't 1943), aff'd, 292 N.Y. 570, 54 N.E.2d 689 (1944).

34. See, e.g., Teren v. Howard, 322 F.2d 949 (9th Cir. 1963); Santarelli v. Katz, 270 F.2d 762 (7th Cir. 1959); Irwin v. West End Dev. Co., 342 F. Supp. 687 (D. Colo. 1972); Herald Co. v. Bonfils, 315 F. Supp. 497 (D. Colo. 1970); Seitz v. Union Brass \& Metal Mfg. Co., 152 Minn. 460, 189 N.W. 586 (1922); Ruetz v. Topping, 453 S.W.2d 624 (Mo. Ct. App. 1970).

35. See, e.g., Teich v. National Castings Co., 201 F. Supp. 451 (N.D. Ohio 1962); Nordin v. Kaldenbaugh, 7 Ariz. App. 9, 435 P.2d 740 (Ct. App. 1967); Chambers v. Beaver-Advance Corp., 392 Pa. 481, 140 A.2d 808 (1958). See also Rebell v. Muscat, 26 App. Div. 2d 685, 272 N.Y.S.2d 478 (Sup. Ct. 1966) (stockholders are entitled to a preliminary injunction to prevent directors pendente lite from exercising certain stock options where the plaintiff-shareholders demonstrated a sufficient probability of success in the litigation). See generally 5 FLeTCHER § 2174, at 687.

36. See, e.g.. Berkwitz v. Humphrey, 163 F. Supp. 78 (N.D. Ohio 1958); Bermann v. Meth, 436 Pa. 88, 258 A.2d 521 (1969); Nordin v. Kaldenbaugh, 7 Ariz. App. 9, 435 P.2d 740 (Ct. App. 1967); Gallin v. National City Bank, 152 Misc. 679, 273 N.Y.S. 87 (Sup. Ct. 1934).

37. See Trainor v. Berner, 334 F. Supp. 1143, 1149 (S.D.N.Y. 1971).

38. See, e.g., In re Brantman, 244 F. 101 , 103 (2d Cir. 1917); Brown v. DeYoung, 167 IIl. 549, 47 N.E. 863 (1897); Keough v. St. Paul Milk Co., 205 Minn. 96, 285 N.IV. 809 (1939); Gottfried v. Gottfried, 73 N.Y.S.2d 692 (Sup. Ct. 1947); Patton v. Nicholas, 279 S.W.2d 848 (Tex. 1955).

39. See, e.g., Irwin v. West End Dev. Co., 342 F. Supp. 687 (D. Colo. 1972); Ruetz v. Topping, 453 S.IV.2d 624 (Mo. Ct. App. 1970); Sandfield v. Goldstein, 33 App. Div. 2d 376, 308 N.Y.S.2d 25 (1970); Bermann v. Meth, 436 Pa. 88, 258 A.2d 521 (1969).

40. See, e.g., Teich v. National Castings Co., 201 F. Supp. 451 (N.D. Ohio 1962) (individually and as a representative stockholder); Binz v. St. Louis Hide \& Tallow Co., 378 S.W.2d 228 (Mo. Ct. App. 1964); Baker v. Cohn, 291 N.Y. 762, 52 N.E.2d 965, 42 N.Y.S.2d 159 (Sup. Ct. 1942), modified, 266 App. Div. 715, 40 N.Y.S.2d 623 (1st Dep't 1943), aff'd, 292 N.Y. 570, 54 N.E.2d 689 (1944); Murrell v. Elder-Beerman Stores Corp., 16 Ohio Misc. 1, 239 N.E.2d 248 (C.P. 1968).

41. See, e.g., Teich v. National Castings Co., 201 F. Supp. 451 (N.D. Ohio 1962); Chalverus v. Wilson Mfg. Corp., 212 Ga. 612, 94 S.E.2d 736 (1956); Jones v. Van Heusen Charles Co., 230 App. Div. 694, 246 N.Y.S. 204 (3d Dep't 1930).

42. See, e.g., Teich v. National Castings Co., 201 F. Supp. 451 (N.D. Ohio 1962); Gruber v. Chesapeake \& O. Ry., 158 F. Supp. 593, 603 (N.D. Ohio 1958); Meiselman v. Eberstadt, 39 Del. Ch. 563, 568, 170 A.2d 720, 723 (1961); Sandfield v. Goldstein, 33 App. Div. 2d 376, 308 N.Y.S.2d 25 (1970); Murrell v. Elder-Beerman Stores Corp., 16 Ohio Misc. 1, 8, 239 N.E.2d 248, 256 (C.P. 1968); Bermann v. Meth, 436 Pa. 88, 258 A.2d 521 (1969). See generally 2 O'NEAL $\$ 8.12$, at 101 . 


\section{The "Reasonableness" Test and the "Business Judgment" Rule}

Notwithstanding the common law presumption that directors served gratuitously ${ }^{43}$ in circumstances where a director served as an officer under an agreement providing for remuneration, courts were reluctant to tamper with whatever compensation level the directors concluded was just. ${ }^{44}$ This historical judicial deference has largely survived the transition of corporations from control by directors with large stockholdings to management by "outsider" executives with minimal stockholdings. When compensation plans have been attacked, courts have consistently articulated and followed the traditional approach, premised upon the business judgment rule, whereby good-faith execution of duties and the adherence to proper corporate procedures by directors leaves little room for judicial review of executive compensation. ${ }^{45}$ On the other hand, instances of "self-dealing," whereby office-holding directors fixed their own compensation without obtaining shareholder ratification, have consistently evoked judicial intervention and appropriate relief. ${ }^{46}$ In the same vein, courts have not hesitated to strike down rctroactive executive bonuses which were not paid pursuant to a prior agreement between the corporation and the executive on the grounds that such bonuses were unsupported by consideration and therefore constituted a gift of corporate assets. ${ }^{47}$

43. See note 6 supra and accompanying text.

44. See, e.g., Church v. Harnit, 35 F.2d 499 (6th Cir. 1929); National Loan \& Inv. Co. v. Rockland Co., 94 F. 335, 338 (8th Cir. 1899); Calkins v. Wire Hardware Co., 267 Mass. 52, 67,165 N.E. 889, 896 (1929); Rocky Mountain Powder Co. v. Hamlin, 73 Nev. 87, 310 P.2d 404 (1957). See generally Annot., 175 A.L.R. 554 (1948).

45. See. e.g., Gruber v. Chesapeake \& O. Ry., 158 F. Supp. 593, 603 (N.D. Ohio 1958); Sandfield v. Goldstein, 33 App. Div. 2d 376, 308 N.Y.S.2d 25 (1970); Heller v. Boylan, 29 N.Y.S.2d 653, 680 (Sup. Ct.), aff'd without opinion, 263 App. Div. 815, 32 N.Y.S.2d 131 (1941); Murrell v. Elder-Beerman Stores Corp., 16 Ohio Misc. 1, 10, 239 N.E.2d 248, 256 (C.P. 1968). See generally BALlanTiNE, supra note 6, at $\S 76 ; 5$ FLETCHER $\$ \$ 2122-33$; Emcrson \& Massey, Remuneration of Officers and Directors of Listed California, Florida, Ohio and Virginia Corporations, 12 U. FLA. L. REV. 156, 157 (1959).

46. See, e.g., Santarelli v. Katz, 270 F.2d 762 (7th Cir. 1959); Irwin v. West End Dev. Co., 342 F. Supp. 687, 700-01 (D. Colo. 1972); Glenmore Distilleries Co. v. Seideman, 267 F. Supp. 915 (E.D.N.Y. 1967); Binz v. St. Louis Hide \& Tallow Co., 378 S.W.2d 228 (Mo. Ct. App. 1964). See generally BALLANTINE, supra note 6 , at $\S 74 ; 2$ O'NEAL $\S 8.12 ; 2$ WaSHINGTON \& ROTHSCHILD 864-67.

47. See, e.g., Hurt v. Cotton States Fertilizer Co., 159 F.2d 52 (5th Cir.), cert. denied, 331 U.S. 828 (1947); Spaeth v. Journal Printing Co., 139 F. Supp. 188, 191-92 (D. Alas. 1956); Baker v. Cohn, 291 N.Y. 762, 52 N.E.2d 965, 42 N.Y.S.2d 159 (Sup. Ct. 1942), modified, 266 App. Div. 715, 40 N.Y.S.2d 623 (Ist Dep't 1943), affd, 292 N.Y. 570,54 N.E.2d 689 (1944). Cf. Osborne v. Locke Steel Chain Co., 153 Conn. 527, 531, 218 A.2d 526, 530 (1966); Rocky Mountain Powder Co. v. Hamlin, 73 Nev. 87, 91, 310 P.2d 404, 406 (1957). 
But not until the passage of federal securities laws, resulting in the disclosure of theretofore closely-guarded compensation schemes in large corporations, did the courts deal with the issue of the actual amounts paid to corporate executives. ${ }^{48}$

\section{Reasonable Compensation: The Lack of a Definitive Standard}

The Supreme Court's decision in the case of Rogers v. Hill (The American Tobacco Case $)^{49}$ is generally regarded as the classic judicial statement on the subject of executive compensation..$^{50}$ In holding that certain executive bonuses based on increases in corporate earnings should be reexamined and revised by the district court, ${ }^{51}$ the Court indicated that where compensation "has no relation to the value of services for which it is given" and, in effect, "amount[s] to spoliation or waste of corporate property," the level of compensation cannot be justified, even if shareholder ratification was obtained..$^{52}$ Although the opinion set forth the foundations of the reasonableness test, the Court did not decide whether the bonuses involved in the cases were, in fact, unreasonable. Moreover, the Court did not enunciate a definitive test as to what constitutes "reasonable" compensation. Instead, the decision merely established a prerequisite to a showing of unreasonable compensation-spoliation or waste of corporate assets. Similarly, subsequent decisions dealing with the extent of executive compensation have failed to establish a definitive standard of reasonableness. ${ }^{53}$

48. See 2 WASHINGTON \& RotHSCHILD 919. See notes 11 \& 12 supra and accompanying text.

49. 289 U.S. 582 (1933).

50. See 2 WASHINGTON \& ROTHSCHILD 880-89. "Both because of the legal principles established and the magnitude of the recovery, the first American Tobacco case remains the leading decision upon the question of excessive compensation." Id. at 880 .

51. The Supreme Court had granted certiorari after the Second Circuit's affirmance of the federal district court's dismissal of plaintiff's bill on the merits. 62 F.2d 1079 (2d Cir.), cert. granted, 289 U.S. 716 (1933). Federal jurisdiction rested on diversity of citizenship. The suit was brought by a stockholder against the company's president and some of its vice-presidents to force them to account to the corporation for allegedly excessive bonuses paid pursuant to a scheme based on a percentage of corporate profits. Under the system, payments made to the president of the corporation, including salary, bonus, and special cash credits, totaled over $\$ 1.2$ million for the year 1930. Two of the vice-presidents received payments totaling over $\$ 500,000$ in that year. The Supreme Court reversed and remanded to the district court. 289 U.S. 582 (1933). On remand, an order providing for retention of the bonus system, but restricting the amounts to be paid in the future, was entered by consent, thereby terminating the case. $34 \mathrm{~F}$. Supp. 358 (1934). See 2 WASHINGTON \& RothsCHILD 880-83.

52. 289 U.S. at $591-92$.

53. See, e.g., Holthusen v. Edward G. Budd Mfg. Co., 52 F. Supp. 125 (E.D. Pa. 1943); Keough v. St. Paul Milk Co., 205 Minn. 96, 285 N.W. 809 (1939); Heller v. Boylan, 29 
The judicial consensus as to what, in fact, constitutes "wasteful" compensation has gone little beyond the recognition that it results from

[f]ailure to relate the amount of compensation to the needs of the particular situation by any recognized business practices, honestly even though unwisely adopted, [and from] bad faith or . . . a total neglect of or indifference to such practices. .....5

Merely "excessive" compensation, resulting from the exercise of "poor judgment," is distinguished from "wasteful" compensation and is not regarded as unlawful or unreasonable. ${ }^{55}$

Instead of establishing precise criteria for review, the courts, in addition to scrutinizing the method of compensation for irregularities in the procedures followed in enacting the particular plan, have articulated a list of factors to which varying degrees of weight are accorded in determining whether the amount of compensation constitutes "waste" of corporate assets-that is, whether payments bear a "reasonable relation to services rendered." Factors which the courts have considered in this regard include: comparison of the compensation in question with remuneration of executives who have comparable responsibilities in the same industry or within the company in question; ${ }^{56}$ the executive's previous earnings; ${ }^{57}$ the success of the company during the executive's term of employment; ${ }^{58}$ and the loss of purchasing power resulting from inflation. ${ }^{59}$

Disparities in salary patterns with regard to such considerations

N.Y.S.2d 653 (Sup. Ct. 1941); Gallin v. National City Bank, 152 Misc. 679, 704, 273 N.Y.S. 87, 115 (Sup. Ct. 1934).

54. McQuillen v. National Cash Register Co., 27 F. Supp. 639, 653 (D. Md. 1939), affd, 112 F.2d 877 (4th Cir.), cert. denied, 311 U.S. 695 (1940).

55. Id.

56. See Meiselman v. Eberstadt, 39 Del. Ch. 563, 568, 170 A.2d 720, 722-23 (1961); Ruetz v. Topping, 453 S.W.2d 624 (Mo. Ct. App. 1970); Gottfried v. Gottfried, 112 N.Y.S.2d 431 (Sup. Ct. 1952).

57. See Heise v. Earnshaw Publications, 130 F. Supp. 38 (D. Mass. 1955); Jaffe v. Chicago Warehouse Lumber Co., 4 Ill. App. 2d 415, 124 N.E.2d 618 (1954).

58. See Irwin v. West End Dev. Co., 342 F. Supp. 687, 701 (D. Colo. 1972); Glenmore Distilleries Co. v. Seideman, 267 F. Supp. 915 (E.D.N.Y. 1967); Ruetz v. Topping, 453 S.W.2d 624 (Mo. Ct. App. 1970).

59. See Poutch v. National Foundry \& Mach. Co., 147 Ky. 242, 143 S.IV. 1003 (1912); Riddle v. Mary A. Riddle Co., 142 N.J. Eq. 147, 59 A.2d 599 (1948). See also 2 Washington \& ROTHSCHILD 856-63. It is notable that all of these factors, with the exception of company success, focus upon considerations relevant only to the salaried officers. As a response to the complaint of a dissident shareholder, who is seeking more equitable dividend treatment, the factors are virtually irrelevant. 
as the industry average compensation for a given managerial position may not, in themselves, move a court to invalidate challenged compensation. ${ }^{60}$ However, in situations where the defendant has the burden of demonstrating the reasonableness of compensation because self-dealing was involved, failure to relate the salaries at issue to such comparative criteria may create a presumption of unreasonableness. ${ }^{61}$

Despite the incorporation of these factors into the basic reasonableness test outlined in Rogers v. Hill, courts remain reluctant to interfere with the business judgment of directors as to what constitutes reasonable executive compensation. ${ }^{22}$ This judicial attitude is accurately reflected in the much-quoted dicta of Justice Collins of the Supreme Court of New York in a decision upholding a challenged compensation scheme:

Courts are ill-equipped to solve or even to grapple with these entangled economic problems. Indeed, their solution is not within the juridical province. Courts are concerned that corporations be honestly and fairly operated by its [sic] directors, with the observance of the formal requirements of the law; but what is reasonable compensation for its officers is primarily for the stockholders. ${ }^{\text {B3 }}$

In view of this judicial reluctance to interfere with the exercise of business judgment by directors, courts have tended to require a showing of fraud, bad faith, or a clear abuse of fiduciary duty before invalidating excessive compensation. ${ }^{64}$ Alternatively, where compensation is so glaringly excessive as to dictate that relief be granted, the courts have preferred to dispose of the cases on grounds of irregularities in corporate procedure. ${ }^{65}$

60. See Meiselman v. Eberstadt, 39 Del. Ch. 563, 568, 170 A.2d 720, 722-23 (1961) (compensation which is somewhat more than average salaries in the industry held not "necessarily excessive" when "there is no shoeking disparity").

61. See Ruetz v. Topping, 453 S.W.2d 624 (Mo. Ct. App. 1970) (judgment for defendant officers reversed since they had failed to demonstrate that their salaries were in line with salaries of officers having similar duties in comparable companies of the same industry; additionally, failure to pay dividends and lack of corporate success indicated that salaries were not reasonable).

62. See, e.g., Gruber v. Chesapeake \& O. Ry., 158 F. Supp. 593, 603 (N.D. Ohio 1957); Murrell v. Elder-Beerman Stores Corp., 16 Ohio Misc. 1, 10, 239 N.E.2d 248, 256 (C.P. 1968). See also 2 O'NEAL § 8.12, at 101; 2 WASHINGTON \& RothsCHILD 852; Note, Judicial Attitude Towards Executive Compensation, 29 U. CIN. L. REv. 245-47 (1960).

63. Heller v. Boylan, 29 N.Y.S.2d 653, 680 (Sup. Ct. 1941).

64. Gruher v. Chesapeake \& O. Ry., 158 F. Supp. 593, 603 (N.D. Ohio 1958). See also BallantiNe, supra note 6, at § 76; Emerson \& Massey, Remuneration of Officers and Directors of Listed California, Florida, Ohio and Virginia Corporations, 12 U. FLA. L. Rev. 15657 (1959).

65. See generally 2 WASHINGTON \& RothSCHILD 852. Typical of the irregularities seized 


\section{Judicial Review of Compensation in Close Corporations: The REQUIREMENT OF SELF-DEALING}

Despite the unique opportunities for "oppression" of minority shareholders existing in a close corporation, ${ }^{60}$ the same judicial deference to the discretion of directors evident in cases involving publicly held corporations largely precludes substantive review of compensation in the close corporation as well ${ }^{67}$ Reflecting this reluctance on the part of the courts to scrutinize the amounts actually paid, the same loosely defined reasonableness test has developed in the close corporation cases.

In close corporation litigation, however, there appears to be an additional barrier to a successful shareholder attack on excessive compensation. A detailed survey by Washington and Rothschild of 67 cases where executive compensation was challenged in close corporations revealed 23 instances in which compensation was held to be unreasonable..$^{68}$ In all but on ${ }^{69}$ of the cases finding that compensation was unreasonable, the decisions were based upon a determination that the compensation had been "self-dealt"- that is, the salaried executive served on the board of directors which approved his salary. If self-dealing does not exist, however, the dissident shareholder bears the burden of proving bad faith or negligent waste of corporate assets. ${ }^{70}$ The Washington and Rothschild survey concluded that this

upon by the courts are self-dealing by directors in voting compensation for themselves as officers; absence of consideration when retroactive bonuses are voted without prior agreement; and miscalculation of bonuses tied to increases in corporate sales or profits. For a leading case where erroneous calculation of the profits on which bonuses were based led to significant overpayments and resulted in a court order that the executives refund the overpayments to the company, see Heller v. Boylan, 29 N.Y.S.2d 653 (Sup. Ct. 1941). See also Winkelman v. General Motors Corp., 44 F. Supp. 960, 967 (S.D.N.Y. 1942).

66. See generally O'NEAL \& DERWIN, supra note 20.

67. Sce 2 O'Neal $\S 8.12$, at 101 . Professor O'Neal further observes:

Perhaps the courts' concern about usurping functions of the board is misplaced in compensation cases arising out of close corporations, because close corporations seldom if ever have independent and disinterested direetors making the decisions on compensa-

tion. ... Id.

68. 2 WASHINGTON \& ROTHSCHILD 865-67.

69. See Dwight v. Williams, 25 Misc. 667, 55 N.Y.S. 201 (Sup. Ct. 1898), in whieh the financial failure of the corporation had resulted in appointment of a receiver. The salaries continued to be paid to executives under the receivership.

70. 2 WASHINGTON \& ROTHSCHILD 867. It is only when "self-dealing" is established that the burden of proof shifts to the executives or directors to justify the payments. See Ruetz v. Topping, 453 S.W.2d 624 (Mo. Ct. App. 1970); Binz v. St. Louis Hide \& Tallow Co., 378 S.W.2d 228 (Mo. Ct. App. 1964). However, in view of the defendant-executive's greater aecess to information relevant to a determination of reasonableness, it is at least arguable that he 


\section{burden was virtually insurmountable. ${ }^{71}$}

By. imposing, in effect, a threshold requirement of self-dealing, courts may be affording dominant executive groups in close corporations an opportunity to avoid meaningful judicial review of their compensation practices, even if self-dealing is present. Although "self-dealt" compensation is presumptively voidable, ${ }^{72}$ if not void, ${ }^{73}$ the presumption may be rebutted by subsequent shareholder ratification. ${ }^{74}$ Since the dominant executives in close corporations normally constitute the majority shareholder group as well, ratification of the directors' action is often a mere formality. ${ }^{75}$ To exacerbate the prob-

should bear the burden of proof in the first instance, as is the case in tax litigation where deducted compensation is challenged by the Commissioner as unreasonable. See, e.g., Charles McCandless Tile Serv. v. United States, 422 F.2d 1336, 1339 (Ct. Cl. 1970). Washington and Rothschild's 67-case survey revealed 21 cases in which compensation was upheld as reasonable where the defendant had the burden of proof because of self-dealing. 2 WASHINGTON \& ROTHSCHILD 865-66. In light of this relative success, it would seem that permanently shifting the burden of proof would not produce unduly harsh results.

71. Id. at 867.

72. See Moore v. Herrink, 77 F.2d 96 (4th Cir. 1935); Gallin v. National City Bank, 152 Misc. 679, 707, 273 N.Y.S. 87, 118 (Sup. Ct. 1934).

73. See Karns v. Industrial Comm'n, 50 Ariz. 466, 73 P.2d 104 (1937). See generally 2 O'NeAL $\S 8.10$, at 83 .

74. See 2 O'Neal $\S 8.10$, at 85 .

75. The traditional rule has been that a contract between a director and his corporation may be ratified at a shareholders' meeting at which the interested director votes as a shareholdcr. See FLETCHER § 761, at 1069. This principle was articulated in the English case of North-IVest Trans. Co. v. Beatty, 12 App. Cas. 589 (P.C. 1887) (Ont.), wherein it was held that the majority vote of the shareholders, including the director who was interested in the contract, must prevail unless the ratification was effected by improper or unfair means. The distinction recognized by common law with respect to interested directors and interested shareholders is related to the fact that a director acts in a fiduciary capacity on behalf of the corporation, whereas an ordinary shareholder is properly entitled to act out of self-interest. See Smith v. Brown Borhek Co., 414 Pa. 325, 200 A.2d 398 (1964). For cases upholding the director's right to vote his shares at a stockholders' meeting on a matter in which he is interested, see, e.g., Boss v. Boss, 200 A.2d 231 (R.I. 1964); Bjorngaard v. Goodhue County Bank, 49 Minn. 483, 52 N.W. 48 (1892). However, in contrast to the traditional approach, a recent federal case, in purporting to apply state law, held tbat there can be no effective stockholder ratification of a fraudulent transaction of the directors where a majority of the shares which are voted at the shareholders' meeting are held by those "interested" in the transaction. Pappas v. Moss, 393 F.2d 865, 868 (3d Cir. 1968). In Pappas, the court applied what it deemed to be controlling New Jersey law, as stated by the Supreme Court of New Jersey. See Brundage v. New Jersey Zinc Co., 48 N.J. 450, 226 A.2d 585 (1967). However, the Brundage case involved a proposed merger between companies having common directors, a factor which the defendants in the case expressly acknowledged as placing the burden of proof on the party seeking to uphold the transaction. Id. at 476, 226 A.2d at 599. Indeed, Pappas itself similarly. involved a basic corporate reorganization. The extraordinary nature of directors' decisions in Brundage and Pappas, due to proposed radical changes in corporate structure, are clearly distinguishable from the more routine decision-making with respect to compensation of executives. 
lem of maintaining control over executive compensation, an increasing number of states have modified their corporation statutes to expressly authorize self-voted compensation in close corporations. ${ }^{70}$ Furthermore, even where self-dealing is neither ratified by shareholders nor authorized by statute, it is not sufficient grounds per se for invalidating compensation. Indeed, courts have not uncommonly upheld precisely such compensation. ${ }^{77}$

Traditional judicial hesitancy to interfere with the extent of executive compensation, and the consistent invocation of the business judgment rule in refusing to examine substantively the reasonableness of compensation policy, can perhaps best be explained by the absence of any manageable criteria to apply in evaluating the amounts actually paid to corporate managers. ${ }^{78}$ Courts cannot reasonably be expected to respond sympathetically to a plaintiff's mere allegation that a given amount, even if substantial, is "unreasonable." Unusually high compensation may be justified by unusual responsibilities assumed or duties performed. ${ }^{79}$ And yet, where self-dealing, fraud, or obvious oppression cannot be demonstrated, the dissident shareholder usually lacks clear evidence upon which to base his claim that compensation is excessive or wasteful. ${ }^{80}$ Comparison with compensation paid other executives has been largely unavailing due to the great variations in company size and duties performed by officers of similar classification, even within the same industry. ${ }^{81}$

Reference to the corporation's relative prosperity, or lack thereof, during the executive's term of employment is more likely to evoke judicial response, ${ }^{82}$ but such intervention almost invariably is triggered by a finding that self-dealing was involved ${ }^{83}$ Moreover, favor-

76. See statutes cited at note 18 supra.

77. See note 70 supra and accompanying text.

78. See, e.g., Heller v. Boylan, 29 N.Y.S.2d 653 (Sup. Ct. 194l), where the court recited typical reasons for refusing to declare compensation unreasonable:

It is not timidity, however, which perturbs me. It is finding a rational or just gauge for revising these figures were I inclined to do so. No blueprints are furnished. The elements to be weighed are incalculable; the imponderables, manifold. Id. at 679 .

79. See Meiselman v. Eberstadt, 39 Del. Ch. 563, 568, 170 A.2d 720, 723 (1961).

80. See 2 WASHINGTON \& ROTHSCHILD 852-63.

81. See id. at 856-57.

82. See, e.g., Irwin v. West End Dev. Co., 342 F. Supp. 687, 701 (D. Colo. 1972); Glenmore Distilleries Co. v. Seideman, 267 F. Supp. 915,919 (E.D. N.Y. 1967); Ruetz v. Topping, 453 S.W.2d 624, 630-31 (Mo. Ct. App. 1970). See also 2 WAsHington \& RothsCHILD 857-59.

83. For instance, in several cases involving "self-dealing," the lack of relative corporate prosperity was cited as a factor in invalidating compensation. See, e.g., Irwin v. West End Dev. Co., 342 F. Supp. 687, 701 (D. Colo. 1972); Glenmore Distilleries Co. v. Seideman, 267 F. 
able case precedents are of limited utility with respect to executive compensation, due to the unique nature of each corporate situation. ${ }^{84}$ Obviously, adoption of a novel approach is dictated if dissident shareholders are to successfully challenge executive compensation.

Although more current compensation cases reveal only limited departures from traditional rules of review, the recent decisions occasionally demonstrate that the business judgment principle is not inviolable. ${ }^{85}$ For example, judicial hesitancy to interfere with internal corporate affairs was overcome in the case of Berkwitz $v$. Humphrey. ${ }^{86}$ In striking down a profit-sharing and retirement plan which was based on valid consideration ${ }^{87}$ and passed by a disinterested board of directors, the court reached a result which demonstrated that mere adherence to proper corporate procedures in adopting compensation plans would not insulate such plans from judicial scrutiny. Since the court found that the compensation plan included post-retirement awards which were tied to increases in the market value of the company's stock subsequent to the employee's retirement, the scheme was declared "unreasonable per se" since it bore no logical relationship to services rendered by employees participating in the plan. ${ }^{88}$ As a result, the court concluded that promulgation of the plan constituted, in effect, a gift of corporate funds. ${ }^{89}$

Although litigation concerning compensation schemes subsequent to Berkwitz has not been characterized by a fundamental departure from the business judgment rule, certain results at least suggest that where generous compensation of corporate executives results in restrictive dividend policies by the corporation, the courts will be less

Supp. 915,919 (E.D.N.Y. 1967); Ruetz v. Topping, 453 S.W.2d 624, 630-31 (Mo. Ct. App. 1970). See also 2 WASHINGTON \& RothSCHILD 864-67.

84. See 2 WASHINGTON \& RothsCHILD 924.

85. See, e.g., Santarelli v. Katz, 270 F.2d 762 (7th Cir. 1959); Herald Co. v. Bonfils, 315 F. Supp. 497 (D. Colo. 1970); Glenmore Distilleries Co. v. Seideman, 267 F. Supp. 915 (E.D.N.Y. 1967); Berkwitz v. Humphrey, 163 F. Supp. 78 (N.D. Ohio 1958); Ruetz v. Topping, 453 S.W.2d 624 (Mo. Ct. App. 1970); Mann v. Luke, 272 App. Div. 19, 68 N.Y.S.2d 313 (1947).

86. 163 F. Supp. 78 (N.D. Ohio 1958).

87. The executives involved in the plan were required to remain in the company's employment subsequent to the execution of the agreement as a condition of eligibility for the benefits. Id. at 89.

88. Id. at 90-93.

89. Id. at 90-93. The response to the case was not one of unanimous approval. See Lieberman v. Becker, 155 A.2d 596 (Del. Sup. Ct. 1959). See also 72 Harv. L. Rev. 375 (1958), which, like Lieberman, rejected the reasoning of Berkwitz. 
willing to defer to directorial discretion..$^{90}$ A notable case illustrating this tendency is Santarelli v. Katz. ${ }^{91}$ In Santarelli, the Seventh Circuit reversed the trial court's dismissal of a derivative action, in which the plaintiffs alleged the existence of excessive executive compensation in a family-controlled close corporation, primarily on the basis of unauthorized self-dealing. However, as further justification for reversal, the court suggested that the defendants' "complete control" of the corporation might well have resulted in unfair dividend treatment for minority shareholders. ${ }^{92}$ In doing so, the court articulated a persuasive rationale for penetrating the business judgment rule:

Normally, a stockholder bringing a derivative suit against the management of a corporation carries a heavy burden. Courts are properly reluctant to interfere in corporate matters that are traditionally regarded as being within the ambit of "business judgment." However, if a stockholder is being unjustly deprived of dividends that should be his, a court of equity will not permit management to cloak itself in the immunity of the business judgment rule..$^{93}$

The rationale advanced in Santarelli, with its suggestion that the business judgment rule does not justify compensation practices which result in improper denial of dividends, has rarely been applied by the courts as sufficient grounds for invalidating compensation. The paucity of dividend declarations may be combined with other relevant factors, however, to convince the court that compensation is unreasonable. ${ }^{94}$ Nonetheless, the prevalent approach of the courts in re-

90. Santarelli v. Katz, 270 F.2d 762, 768 (7th Cir. 1959); Herald Co. v. Bonfils, 315 F. Supp. 497 (D. Colo. 1970); Ruetz v. Topping, 453 S.W.2d 624, 632 (Mo. Ct. App. 1970). For earlier cases to the same effect, see Stearns v. Dudley, 76 N.Y.S.2d 106, 127-28 (Sup. Ct.), aff d, 86 N.Y.S.2d 478 (App. Div. 1948); Mann v. Luke, 44 N.Y.S.2d 202 (Sup. Ct. 1943), aff d, 272 App. Div. 19, 26 N.Y.S.2d 313 (1947), settlement approved, 82 N.Y.S.2d 725 (Sup. Ct. 1948); Baker v. Cohn, 42 N.Y.S.2d 159, 166-67 (Sup. Ct. 1942), modified, 266 App. Div. 715, 40 N.Y.S.2d 623 (1st Dep't 1943), affd, 292 N.Y. 570, 54 N.E.2d 689 (1944).

91. 270 F.2d 762 (7th Cir. 1959). The Santarelli case involved a broad attack upon the management of a close corporation in which misappropriation of corporate assets and diversion of corporate opportunities were alleged by a minority shareholder trust beneficiary. The allegations involving excessive compensation centered upon annual payments averaging $\$ 11,375$ per year made to the wife of the chairman of the board of directors of the corporation. The wife of the chairman was also a director, and her "services rendered" to the corporation consisted largely of attending "three or four conventions a year." The court of appeals reversed the district court's dismissal of the complaint and directed that, on remand, the burden would be on the defendants to show the reasonableness of their self-determined compensation. Id. at 768. 69.

92. Id. at 768.

93. Id. (emphasis added).

94. See Herald Co. v. Bonfils, 315 F. Supp. 497, 503 (D. Colo. 1970), where the court stated: "[N]or is it permissible by payment of excessive salaries or allowances to divert funds 
viewing executive compensation still requires little more than refraining from obvious waste in order to avoid liability for excessive compensation. Thus, in a case involving fees paid an investment adviser in a mutual fund, a Delaware court indicated that

[w] here waste of corporate assets is alleged, the court, notwithstanding independent shareholder ratification, must examine the facts .... [This] examination is limited solely to discovering whether what the corporation has received is so inadequate in value that no person of ordinary sound business judgment would deem it worth what the corporation has paid..$^{95}$

Where self-dealing does not exist, the courts' hesitancy to apply substantive judicial review continues to prevail in the close corporation compensation cases as well. The broad discretion which the courts allow the board of directors in fixing the levels of executive compensation is suggested by the rationale advanced in a recent Ohio decision, which upheld a challenged compensation plan in a close corporation:

The amount of compensation to be paid an officer is within the business discretion of the company's board of directors, having regard to the volume and nature of the business, and the courts are loathe to interfere, even though the amount may appear to be in excess of the value of services rendered. ${ }^{.6}$

This limited extent of judicial review of executive compensation patterns is clearly inadequate to protect the interests of the minority shareholder in the close corporation. Adherence to the business judgment and reasonableness standards places a virtually insurmountable burden of proof upon dissident shareholders in cases where they cannot establish self-dealing. ${ }^{97}$ Moreover, various devices are available to the dominant group in the close corporation by which the issue of self-dealing can be negated. ${ }^{98}$ Invocation of the business judgment rule will, therefore, continue to preclude relief in the vast majority of compensation cases unless manageable judicial criteria can be developed for use in substantive review.

Rather than focusing narrowly on the excessiveness of amounts actually paid as compensation, a method which inevitably comes into

from stockholders to officers or directors, without lawful reason." See also Ruetz v. Topping, 453 S.IV.2d 624 (Mo. Ct. App. 1970), where questionable dividend policies were cited as one of several reasons for invalidating a compensation plan.

95. Saxe v. Brady, 40 Del. Ch. 474, 486, 184 A.2d 602, 610 (1962) (emphasis added).

96. Murrel v. Elder-Beerman Stores Corp., 16 Ohio Misc. 1, 10, 239 N.E.2d 248, 256 (C.P. 1968) (emphasis added).

97. See notes 70-71 supra and accompanying text.

98. See notes 74-77 supra and accompanying text. 
conflict with the business judgment rule, litigants challenging a compensatory scheme might well emphasize the extent to which the plan intrudes upon the shareholder's right to a reasonable return on his investment. As suggested by the reasoning of Santarelli v. Katz, this type of alternative approach may afford the courts a justification for piercing the business judgment rule and broadening the scope of the reasonableness test.

\section{A New Standard of Reasonableness: Focusing on the SHAREHOLDER's Claim TO AN INVESTMENT RETURN}

A possible solution to the problem of providing adequate judicial review of executive compensation can be extracted from a line of recent tax cases where the reasonableness of compensation for tax purposes was in issue. ${ }^{98}$

Quite naturally, tax considerations are an integral part of corporate compensation planning, ${ }^{100}$ especially in the close corporation, where compensation often constitutes the primary channel for distributing corporate profits. ${ }^{101}$ Since a deduction from a corporation's gross income is allowed for reasonable amounts expended for compensation, ${ }^{102}$ the issue of the reasonableness of deducted compensation is frequently before the tax courts. ${ }^{103}$ Although the test of reasonableness applied in the tax cases is roughly similar to that applied in the corporate compensation cases, the tax cases are rarely cited in the corporate law setting. ${ }^{104}$ Significantly, the test of reasonableness applied by the tax courts ${ }^{105}$ is more comprehensive than the standard

99. See, e.g., Charles McCandless Tile Serv. v. United States, 422 F.2d 1336 (Ct. Cl. 1970); Irby Constr. Co. v. United States, 290 F.2d 824 (Ct. Cl. 1961); Northlich, Stolley, Inc. v. United States, 368 F.2d 272 (Ct. Cl. 1966).

100. For an analysis of the tax aspects of executive compensation in the close corporation, as well as practical suggestions for dealing with such problems, see Murdock, supra notc 26, at 146.

101. See 2 Washington \& Rothschild 849.

102. See note 29 supra and accompanying text.

103. See sourccs listed at note 26 supra.

104. See 2 Washington \& RothsCHILD 871-73. But see Ruetz v. Topping, 453 S.W.2d 624, 628 (Mo. Ct. App. 1970), where the court explicitly refcrred to the tax test of "reasonableness" in the course of its opinion.

105. It should be noted that the tax courts must, of necessity, determine whether compensation is reasonable inasmueh as a deduction is permitted by section 162 of the Internal Revenue Code only if the payments are "reasonable." Accordingly, in considering the reasonableness of corporate compensation, the courts are attempting to implement the strong fcderal intcrest in enforcing the tax laws. In contrast, suits instituted by minority shareholders attacking compensation policies involve no equally direct governmental intercst. Moreovcr, judicial scru- 
employed in the corporate setting. ${ }^{106}$

The test applied in the tax cases incorporates consideration of the dividend treatment accorded shareholders in passing upon the reasonableness of compensation which is deducted by the corporation as an ordinary business expense. ${ }^{107}$ Inclusion of the factor of the corporation's dividend policy as an integral part of the reasonableness test distinguishes the tax cases from corporate cases, which have only rarely considered dividend treatment in making a determination of reasonableness. ${ }^{108}$ More significantly, the tax cases have consistently held that even where the challenged compensation may be technically regarded as reasonable, salaries and other payments are not deductible to the extent that they represent corporate earnings properly payable as dividends. ${ }^{109}$

The underlying rationale of this modified test of reasonableness was set forth by the Court of Claims in Charles McCandless Tile Service $v$. United States, ${ }^{110}$ which involved the deductibility of executive compensation in a close corporation. In McCandless, the court held that where an annual return on equity capital of 15 percent of net corporate profits would have been reasonable and just, ${ }^{111}$ and

tiny of compensation patterns necessarily entails intrusion into intracorporate disputes, a factor which necessarily involvcs overseeing of corporate decision-making. The general hesitance of courts to interfere with business judgment of directors, which stems from a sense that the judiciary is ill-equipped to operate as an ad hoc regulatory body over corporate decisionmaking, applies in the compensation area as well. For these reasons, the approaches and purposes of courts dealing with corporate compensation of executives differ in the tax and corporate law contexts. Nevertheless, as will be indicated later, the methodology used by the tax courts seems equally applicable in the corporate context. See notes 109-119 infra and accompanying text.

106. See Murdock, supra note 26 , at $146-47$.

107. See cases cited at note 99 supra.

108. See note 94 supra and accompanying text.

109. See Charles McCandless Tile Serv. v. United States, 422 F.2d 1336, 1339 (Ct. Cl. 1970); Northlich, Stolley, Inc. v. United States, 368 F.2d 272 (1966); Irby Constr. Co. v. United States, 290 F.2d 824 (Ct. Cl. 1961); Klamath Medical Serv. Bureau v. Commissioner, 29 T.C. 339 (1957), aff d, 261 F.2d 842 (9th Cir.), cert. denied, 359 U.S. 359 (1958); Barton-Gillet Co., 70 P-H Tax Ct. Mem. 750 (1970). It is at least arguable that compensation which is disallowed as a deduction under the tax test should not be able to pass judicial scrutiny when challenged in the corporate law setting. One leading commentator has even suggested that a by-law provision for compulsory reimbursement of the corporation to the extent that compensation fails the tax deduction test would not be inappropriate. See 2 O'NEAL $\S 8.13$, at 109.

110. 422 F.2d 1336 (Ct. Cl. 1970). For a criticism of McCandless in the tax setting, see Alvarez, supra note 26 , at 31 .

111. The court's method in $M c$ Candless of determining the "reasonable and just" dividend return is unclear. As a result, the $M c$ Candless approach is diminished somewhat in terms of its usefulness to a shareholder who attempts to prove the actual extent of excessive compensa- 
where no dividend had been declared, purported compensation in the form of salaries was not deductible by the corporation to the extent that the payments represented a reasonable return on equity capital. ${ }^{12}$ In justifying its refusal to allow a deduction for otherwise reasonable compensation, the court set forth the following rationale:

Implicit in our . . . discussion of reasonable compensation is the attitude that a corporation's highly efficient operation and its clearly demonstrated profitmaking ability justify substantial compensation to the officers responsible therefor. As such performance justifies substantial compensation, we are of the further view that it also justifies a substantial investment return. ${ }^{13}$

In applying this theory, the court held that, to the extent that the compensation constituted a "disguised dividend," such payments were non-deductible. ${ }^{114}$

Inasmuch as due regard is given to whether there has been an equitable return on investment capital, the theory advanced in McCandless views executive compensation in a more realistic perspective than the corporate test of reasonableness which has evolved from Rogers $v$. Hill ${ }^{115}$ Under the $M c$ Candless theory, a corporation is required to make due allowance for dividend returns in the same process whereby it calculates what is reasonable in fixing executive compensation. This approach seems quite sound, for if the corporation is allowed to fix a "reasonable" compensation figure before it determines whether profits are sufficient to justify a dividend, then profits may easily be consumed by merely denominating an overly generous bonus as a "business expense." 110 The company

tion. An approach which could be utilized by the courts would be to determine the appropriate investment return in regard to the nature of the corporation's business-whether the entcrprise is "risky" or comparatively "safe." A lower return would perhaps be warranted if risk were at a minimum than would be true if the enterprise was a high-risk venture. With this crude index serving as a general guideline, the courts could then reasonably look to the dividend rates for stock in public-issue enterprises involving a similar degree of risk for further guidance in determining the precise amount of a rcasonable dividend.

112. 422 F.2d at 1339-40. It should be noted that all of the stock of the corporation involved in McCandless was owned by the two officer/directors whose compensation was being challenged for deductibility. Thus, there were no conflicting equities involved which would dictate the court's overturning the company's dividend policies, other than the government's interest in preventing tax avoidance. Nonetheless, the rationale applied by the court, in concluding that what is reasonable compensation can only be determined in the context of the shareholder's right to reasonable dividend treatment, scems cqually applicable to cases where compensation is challenged in the corporate law setting.

113. Id. at 1340 (emphasis added).

114. Id.

115. See note 49 supra and accompanying text.

116. There is considerable merit in ealculating the profits of a closely held enterprise prior 
could thereupon respond to a shareholder's complaint of unfair dividend treatment by referring to the corporate ledgers and pleading that profits were insufficient to justify a declaration of dividends. If the $M c$ Candless approach were applied to the corporate law setting, however, an aggrieved shareholder could bring an action and require the corporate directors to justify the discrepancy between the generous bonus and the dearth of dividends.

In contrast, under the loose standard of Rogers $v$. Hill, the business judgment rule would normally preclude this type of intensive judicial scrutiny. Moreover, the corporate test of reasonableness focuses too narrowly on considerations relevant only to the salaried executive, such as industry-wide or intra-company salary comparisons, ${ }^{117}$ while it fails to consider reasonableness from the perspective of an appropriate investment return for the shareholder. Particularly in the close corporation, where a dominant faction's interests often lie in minimizing dividends for tax purposes, closer scrutiny of dividend policy should be incorporated into the test of reasonableness of executive compensation. Although expanded judicial review of a corporation's dividend policy might well entail certain theoretical conflicts with the business judgment rule, the principle of judicial deference to directors' discretion is premised upon the theory that existing standards of judicial review are too vague to justify an intrusion into corporate decision-making. $\mathrm{McC}$ Candless and similar tax cases demonstrate that the determination of what constitutes equitable and reasonable dividend treatment in a particular situation is not beyond the purview of the courts.

\section{CONCLUSION}

Judicial review of challenged executive compensation plans has characteristically displayed an exaggerated deference to the business

to allowing a deduction from profits for compensation paid to the corporate officers. Indeed, one study indicates that "officers' compensation must be added back to reported earnings before one can reach a fair idea of a small concern's profitability." 2 WasHiNGTON \& Rothschild 849, citing Merwin, Financial Characteristics of American ManufacturING Corporations 33 (TNEC Monograph No. 15, 1940). Obviously, this analysis should be limited to a determination of the extent of profits from which dividends could be declared; the pre-salary profit figure by no means should be construed as constituting gross income to the corporation for tax purposes inasmuch as, by so doing, the benefits of section 162 of the Internal Revenue Code would be unavailable to the closely held concern. In short, the practice of adding officers' salaries to corporate profits should be used only to determine the extent of the fund potentially available for dividends.

117. See note 56 supra and accompanying text. 
judgment rule. Moreover, in those rare instances in which the actual amounts of compensation have been reviewed as to reasonableness, the test applied by the courts has focused too narrowly on factors relevant only to the salaried officers. Thus, inadequate regard has been accorded to the legitimate interests of the minority shareholder in seeking an equitable return on his investment. In cases involving close corporations, the consistently followed requirement of a threshold demonstration of self-dealing effectively precludes review of challenged compensation in cases where self-dealing cannot be adequately established or where the actionable nature of self-dealing has been negatcd by statute or shareholder ratification. In view of the opportunities for oppressive dividend treatment of minority shareholders in close corporations, ${ }^{118}$ it seems apparent that the tests generally applied by the courts in reviewing challenged compensation fail to provide adequate protection for the interests of an unsalaried, minority shareholder. Since salaried executives dominating a close corporation are in a position to maximize personal profit by enlarging compensation in derogation of dividend return, closer scrutiny of dividend policy should be incorporated in judicial review of executive compensation in the close corporation. Specifically, the courts should consider to what extent, if any, an executive's compensation consumes what may be regarded as a reasonable return on an unsalaried shareholder's invested capital. To that extent, parties responsible for excessive compensation should be required to repay the excess amounts to the corporation, thereby creating a fund out of which dividends could be declared. ${ }^{119}$ The practicability of such a system of judicial review is demonstrated by the recent tax cases, in which the disallowance of tax deductions for ostensibly "reasonable" compensation has been grounded upon explicit judicial findings of what constitutes a "just and reasonable" dividend return in a particular case. Mechanical invocation of the business judgment rule cannot justify inadequate scrutiny of executive compensation when a manageable criterion for review has been established.

118. See generally O'NEAL \& DERwiN, supra note 20.

119. This solution was suggested 75 years ago by the Illinois Supreme Court. See Brown v. DeYoung, 167 Ill. $549,556-58,47$ N.E. 863,866 (1897). 